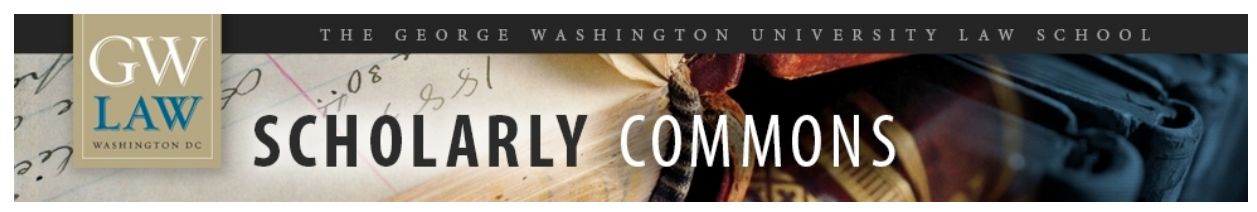

\title{
Supreme Court Brief Of Amicus Curiae Richard J. Pierce, Jr. In Support Of Neither Party
}

\author{
Richard J. Pierce Jr \\ George Washington University Law School, rpierce@law.gwu.edu
}

Follow this and additional works at: https://scholarship.law.gwu.edu/faculty_publications

Part of the Law Commons

\section{Recommended Citation}

Pierce, Richard J., Supreme Court Brief Of Amicus Curiae Richard J. Pierce, Jr. In Support Of Neither Party (November 5, 2019). GWU Law School Public Law Research Paper No. 2019-64; GWU Legal Studies Research Paper No. 2019-64. Available at SSRN: https://ssrn.com/abstract=3483240

This Brief is brought to you for free and open access by the Faculty Scholarship at Scholarly Commons. It has been accepted for inclusion in GW Law Faculty Publications \& Other Works by an authorized administrator of Scholarly Commons. For more information, please contact spagel@law.gwu.edu. 


\title{
$\mathfrak{J n} \mathfrak{T h \mathfrak { e }}$ Wupreme Court of the ofnited States
}

UNITED STATES FOREST SERVICE, ET AL., Petitioners,

V.

COWPASTURE RIVER PRESERVATION ASS'N, ET AL., Respondents.

\section{ATLANTIC COAST PIPELINE, LLC,}

$$
\text { v. }
$$

Petitioner,

COWPASTURE RIVER PRESERVATION ASS'N, ET AL., Respondents.

\author{
$\longrightarrow$ \\ On Writs Of Certiorari To The \\ United States Court Of Appeals \\ For The Fourth Circuit \\ BRIEF OF AMICUS CURIAE \\ RICHARD J. PIERCE, JR. \\ IN SUPPORT OF NEITHER PARTY

RICHARD J. PIERCE, JR.
Counsel of Record
GEORGE WASHINGTON UNIVERSITY
LAW SCHOOL
2000 H Street NW
Washington, DC 20052
(703) 304-1623
rpierce@law.gwu.edu

November 5, 2019 
TABLE OF CONTENTS

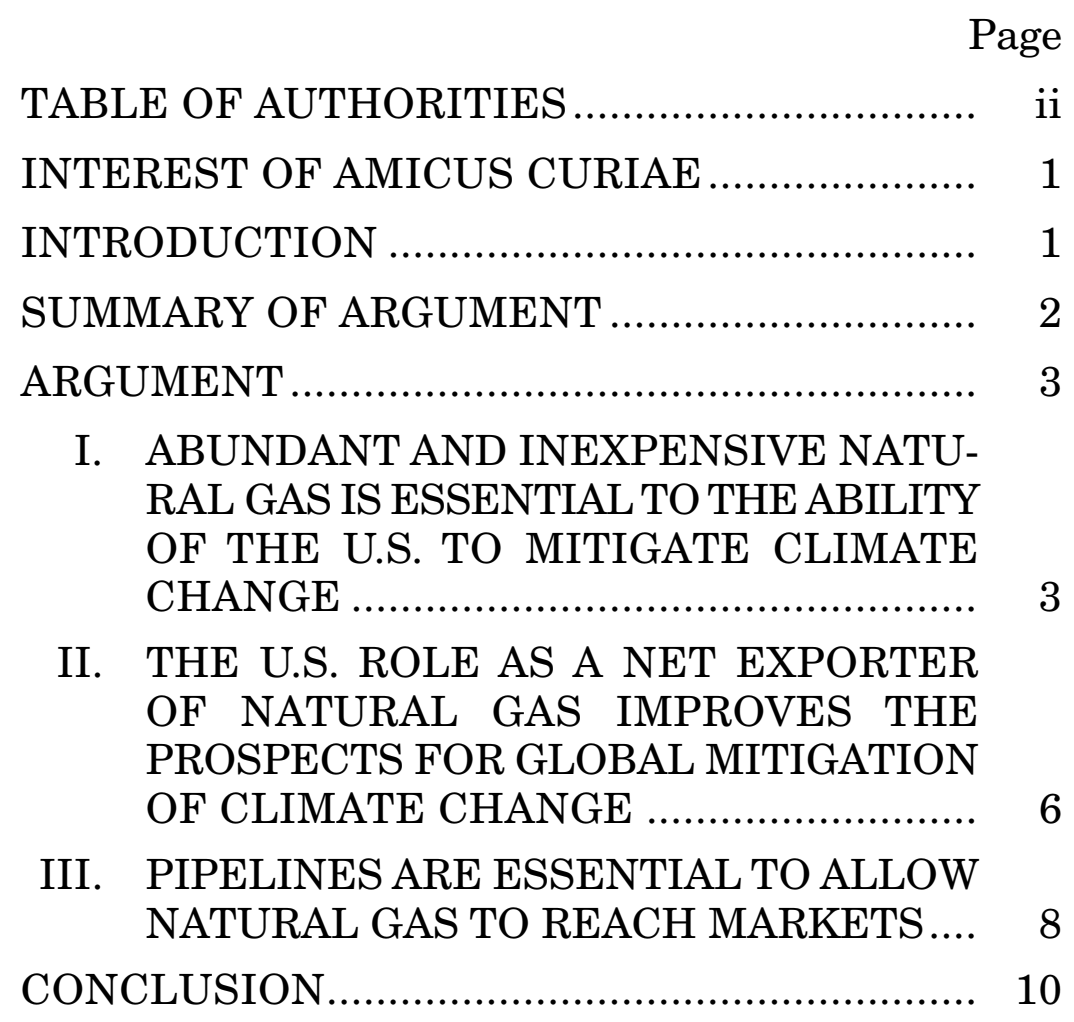


TABLE OF AUTHORITIES

CASES

Northwest Central Pipeline Corp. v. State Corporation Commission of Kansas, 489 U.S. 493 (1989)

Miscellaneous

Alexandra Klass \& Danielle Meinhardt, Transporting Oil and Gas: U.S. Infrastructure Challenges, 100 Iowa L. Rev. 947 (2015) ......................4, 8

Carbon Pollution Emission Guidelines for Existing Stationary Sources: Electric Generating Units, 80 Fed. Reg. 64,661 (Oct. 23, 2015).

Emily Hammond \& Richard Pierce, The Clean Power Plan: Testing the Limits of Administrative Law and the Electric Grid, 7 George Washington Journal of Energy and Environmental Law 1 (Winter 2016).

Endangerment and Cause or Contribute Findings for Greenhouse Gases Under Section 202(a) of the Clean Air Act. 74 Fed. Reg. 66,495 (Dec. 15, 2009)

Energy Information Administration, U.S. Crude Oil and Natural Gas Proved Reserves (Dec. 19, 2014)

Energy Information Administration, U.S. Energy-Related Carbon Dioxide Emissions, 2017 (Sep. 25, 2018) 
iii

TABLE OF AUTHORITIES—Continued

Page

Environmental Protection Agency, CO2 Emission Performance Rate Goal Computation Technical Support Document for CPP Final Rule (Aug. 2013).

Government Accounting Office, Pipeline Permitting: Interstate and Intrastate Natural Gas Permitting Processes Include Multiple Steps, and Time Frames Vary (Feb. 2013) ...

International Energy Agency, IEA Finds CO2 Emissions Flat for Third Straight Year Even As Global Economy Grew in 2016 (Mar. 17, 2017)

International Energy Agency, Global Energy and CO2 Status Report (Oct. 9, 2019) ...............6, 7

Richard Pierce, Natural Gas Fracking Addresses All of Our Major Problems, 4 George Washington Journal of Energy and Environmental Law 22 (Summer 2013)....................................... 7

Richard Pierce, Pipeline Opposition Impedes Climate Change Mitigation, The Regulatory Review (Sep. 13, 2018)

Richard Pierce, State Regulation of Natural Gas in a Federally-Deregulated Market: The Tragedy of the Commons Revisited, 73 Cornell L. Rev. 15 (1987) .10

Yehya M. Nasser, Commoditization of Natural Gas, Challenges and Prospects, Society of Petroleum Engineers SPE-175759-MS (2015). 


\section{INTEREST OF THE AMICUS CURIAE ${ }^{1}$}

Richard J. Pierce, Jr. has been teaching and writing about energy law and policy for over forty years. His books and articles have been cited in many court opinions, including over a dozen opinions of the U.S. Supreme Court. He has no relationship with any party to this case or with any firm that participates in the natural gas market. He is filing this brief in support of neither party to help the Court understand the context in which the case arises.

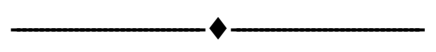

\section{INTRODUCTION}

The question in this case is whether the Forest Service has the power to grant a right of way to a natural gas pipeline to cross beneath the Appalachian $\mathrm{Na}-$ tional Scenic Trail. Amicus takes no position on that issue. Amicus wants to help the Court understand the context in which the question arises and the environmental implications of any decision that would block or delay construction of natural gas pipelines.

${ }^{1}$ No person other than amicus has authored this brief in whole or in part or made a monetary contribution toward its preparation or submission. All parties have consented to the filing of this brief. 


\section{SUMMARY OF ARGUMENT}

An abundant and inexpensive supply of natural gas is essential to allow the U.S. to play a constructive role in mitigating climate change. Use of natural gas to generate electricity emits less than half as much carbon dioxide as use of coal to generate electricity. As a result of advances in horizontal drilling and hydraulic fracturing, the U.S. has increased substantially the amount of natural gas that it produces. That increase in supply has reduced significantly the price of natural gas.

The availability of abundant supplies of inexpensive natural gas has created market conditions in which firms that generate electricity have switched from use of coal to use of natural gas. That, in turn, has allowed the U.S. to reduce significantly the amount of carbon dioxide that is emitted as a result of generating electricity in the U.S. If natural gas remains abundant and inexpensive in the U.S., it will continue to play a major role in allowing the U.S. to mitigate climate change both by encouraging more fuel switching from coal to natural gas and by enabling fuel switching from coal to carbon-free sources like solar and wind.

The abundant and inexpensive supply of natural gas in the U.S. has enabled the U.S. to make a transition from being a net importer of natural gas to being a net exporter of natural gas. The availability of inexpensive natural gas from the U.S. has reduced the price of natural gas in other countries, thereby encouraging them to mitigate climate change by switching from 
high-carbon content coal to low-carbon content natural gas.

A large and growing network of pipelines is essential to allow natural gas produced in the U.S. to continue to play a constructive role in mitigating climate change. In many circumstances, the alternative to transporting natural gas from a producing area to a market or to a liquefied natural gas terminal for export is to flare the natural gas in the producing area. Flaring (controlled burning of natural gas in the atmosphere) is wasteful and contributes to climate change. Any change in the legal environment that has the effect of blocking or delaying construction of natural gas pipelines will impair efforts to mitigate climate change.

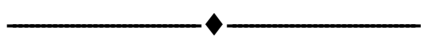

\section{ARGUMENT}

\section{ABUNDANT AND INEXPENSIVE NATURAL GAS IS ESSENTIAL TO THE ABILITY OF THE U.S. TO MITIGATE CLIMATE CHANGE.}

Emissions of carbon dioxide are one of the primary anthropogenic causes of climate change. ${ }^{2}$ Any electricity source that burns fossil fuels emits carbon dioxide. Electric generating plants account for 38 percent of

${ }^{2}$ Endangerment and Cause or Contribute Findings for Greenhouse Gases Under Section 202(a) of the Clean Air Act. 74 Fed. Reg. 66,495, 66,523 (Dec. 15, 2009). 
U.S. carbon dioxide emissions. ${ }^{3}$ The quantity of the emissions from a generating plant depends primarily on the amount of carbon in the fuel. The only economically and technologically feasible method of reducing emissions of carbon dioxide at present is to switch from a high-carbon content fuel to a low-carbon content fuel or a carbon-free fuel. Combustion of natural gas emits less than half as much carbon dioxide as combustion of coal per unit of electricity generated. ${ }^{4}$ Wind and solar are carbon-free sources that emit no carbon dioxide.

Since 2004, the U.S. has more than doubled its reserves of natural gas through use of improved methods of horizontal drilling and hydraulic fracturing. ${ }^{5}$ That dramatic increase in reserves has increased the available supply of natural gas and reduced the price of natural gas. ${ }^{6}$ That change in market conditions has induced many firms that generate electricity to switch from coal to natural gas.

Between 2005 and 2017 U.S. emissions of carbon dioxide declined by 2,360 million metric tons as a

${ }^{3}$ Carbon Pollution Emission Guidelines for Existing Stationary Sources: Electric Generating Units, 80 Fed. Reg. 64,661, 64,677 (Oct. 23, 2015).

${ }^{4}$ Environmental Protection Agency, CO2 Emission Performance Rate Goal Computation Technical Support Document for CPP Final Rule, p. 11 table 4 (Aug. 2013).

${ }^{5}$ Energy Information Administration, U.S. Crude Oil and Natural Gas Proved Reserves (Dec. 19, 2014).

${ }^{6}$ Alexandra Klass \& Danielle Meinhardt, Transporting Oil and Gas: U.S. Infrastructure Challenges, 100 Iowa L. Rev. 947, 999-1006 (2015). 
result of switching from coal to natural gas. ${ }^{7}$ That decline allowed the U.S. to reduce its emissions of carbon dioxide by more than any other country. In 2016, the International Energy Agency credited the U.S. with the largest reduction in carbon dioxide emissions of any country, attributed the reduction to switching from coal to natural gas, solar and wind, and noted that fuel switching had allowed the U.S. to reduce emissions of carbon dioxide to the lowest level since $1992 .{ }^{8}$

As a result of fuel switching, coal's share of electricity generation declined from 52 percent in 1990 to 30 percent in $2017 .{ }^{9}$ If natural gas remains abundant and inexpensive, the remaining 30 percent of electricity that is generated through use of coal will be switched to natural gas or to carbon-free sources. That additional fuel switching will result in additional large reductions in carbon dioxide emissions.

Switching from coal to carbon-free sources like wind and solar yields even larger reductions in carbon dioxide emissions per unit of electricity generated. Between 2005 and 2017, U.S. emissions of carbon dioxide declined by 1,494 metric tons as a result of fuel switching from coal to carbon-free sources of electricity. ${ }^{10}$

${ }^{7}$ Energy Information Administration, U.S. Energy-Related Carbon Dioxide Emissions, 2017, p. 9 (Sep. 25, 2018).

${ }^{8}$ International Energy Agency, IEA Finds CO2 Emissions Flat for Third Straight Year Even As Global Economy Grew in 2016 (Mar. 17, 2017).

${ }^{9}$ Energy Information Administration, supra, note 7, at p. 11.

${ }^{10}$ Id. at p. 9. 
Switching from coal to carbon-free sources depends critically on the continued availability of abundant and inexpensive natural gas. Solar and wind are intermittent sources of electricity. Since electricity cannot be stored economically, solar and wind are viable sources of reliable electricity service only if they are combined with a source that is readily available when the sun does not shine and the wind is not within a range that allows windmills to generate electricity. Natural gas is the only source that can provide that essential backup function in the U.S. ${ }^{11}$

\section{THE U.S. ROLE AS A NET EXPORTER OF NATURAL GAS IMPROVES THE PRO- SPECTS FOR GLOBAL MITIGATION OF CLIMATE CHANGE.}

Coal-fired power generation is the largest source of global energy-related carbon dioxide emissions. In 2018 , it accounted for 30 percent of all energy-related carbon dioxide emissions and 38 percent of emissions from electricity generation globally. ${ }^{12}$ Unfortunately, coal is still growing as a source of electricity. In 2018 it was the largest source of growth in carbon dioxide emissions in the world. Increases in use of coal to

11 Emily Hammond \& Richard Pierce, The Clean Power Plan: Testing the Limits of Administrative Law and the Electric Grid, 7 George Washington Journal of Energy and Environmental Law 1, 12-16 (Winter 2016).

${ }^{12}$ International Energy Agency, Global Energy and CO2 Status Report p. 5 (Oct. 9, 2019). 
generate electricity in China and India more than offset reductions in the U.S., Europe and Japan. ${ }^{13}$

The recent transition of the U.S. from its role as a net importer of natural gas to its new role as a net exporter of natural gas is transforming the global market for natural gas. ${ }^{14}$ That market is rapidly becoming commoditized. ${ }^{15}$ The price of natural gas is increasingly lower than, and disconnected from, the price of oil. The price of natural gas in each country increasingly is linked to the price of natural gas in other countries. Other countries that sell natural gas on the global market have had to reduce the prices they charge in response to the U.S. entry into the market. ${ }^{16}$

If and to the extent that the U.S. continues to expand its role as a global supplier of natural gas, the price of natural gas in other countries will decline. As a result, an increasingly large number of the new electricity generating units will be built to use natural gas rather than coal, and an increasing proportion of existing generation will switch from coal to natural gas.

13 Id. at p. 5.

${ }^{14}$ Richard Pierce, Natural Gas Fracking Addresses All of Our Major Problems, 4 George Washington Journal of Energy and Environmental Law 22, 24-25 (Summer 2013).

15 Yehya M. Nasser, Commoditization of Natural Gas, Challenges and Prospects, Society of Petroleum Engineers SPE175759-MS (2015).

${ }^{16}$ Richard Pierce, supra, note 14, at 24-25. 


\section{PIPELINES ARE ESSENTIAL TO ALLOW NATURAL GAS TO REACH MARKETS.}

Natural gas can only be transported economically over land by pipeline. The large reductions the U.S. has achieved in its emissions of carbon dioxide took place in a legal environment in which it was relatively easy to obtain approval of a proposed natural gas pipeline in a short period of time. Between 2000 and 2011, 14,600 miles of new natural gas pipelines were proposed, approved and built. ${ }^{17}$ The average time required to obtain the certificate required to construct a pipeline was 558 days. $^{18}$

Over the last few years, however, that legal environment has begun to change. Many proposed gas pipelines have been the subject of a variety of new legal challenges. ${ }^{19}$ The concerted efforts of some environmental advocacy organizations to block or delay construction of gas pipelines seem to be related to the "keep it in the ground" movement-groups of citizens who believe that the best way to mitigate climate change is to keep all fossil fuels in the ground. That movement is understandable but misguided.

The keep it in the ground movement is understandable because emissions of carbon dioxide from

17 Klass \& Meinhardt, supra, note 6, at 1007.

18 Government Accounting Office, Pipeline Permitting: Interstate and Intrastate Natural Gas Permitting Processes Include Multiple Steps, and Time Frames Vary, p. 26 (Feb. 2013).

${ }^{19}$ Richard Pierce, Pipeline Opposition Impedes Climate Change Mitigation, The Regulatory Review (Sep. 13, 2018). 
fossil fuels are the most important source of anthropogenic climate change. The movement is misguided, however, for several reasons.

First, the use of natural gas to generate electricity produces less than half the quantity of emissions of carbon dioxide as does the use of coal. Coal remains a major source of electricity in the U.S. today, so the U.S. still has the opportunity to reduce its carbon dioxide emissions significantly by switching from coal to gas.

Second, coal remains the largest source of electricity in the world. The U.S. change in its role from that of a net importer of natural gas to a net exporter of natural gas has reduced the global price of natural gas. That price change has increased the probability that generators of electricity in other nations will build new generating plants to use natural gas rather than coal and will switch some of their existing generators from coal to natural gas. That will mitigate climate change by reducing emissions of carbon dioxide. The U.S. can continue to play that constructive role in global energy markets only if it continues to have an abundant supply of inexpensive natural gas that is available for export.

Third, without major new technological improvements in large-scale storage of electricity, it is impossible to maintain a reliable supply of electricity without access to an abundant supply of inexpensive natural gas as a backup fuel for use when the sun does not shine and wind velocity is outside the range that allows windmills to function. 
Fourth, the alternative to providing the pipeline capacity needed to transport natural gas from supply areas to markets often is wasteful flaring of natural gas. A high proportion of natural gas is produced in conjunction with oil. Even if efforts to block oil pipelines are successful, oil can be transported to markets by rail or truck. In many circumstances, the inability of producers to transport natural gas to markets creates a powerful economic incentive to flare the natural gas, i.e., to burn it in the air. ${ }^{20}$ Flaring both causes waste and increases anthropogenic climate change.

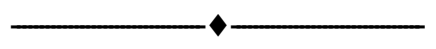

\section{CONCLUSION}

In deciding this case, the Court should consider the context in which the case arises. It is impossible to take many of the actions that are critical to mitigation of climate change unless the U.S. continues to have an abundant supply of inexpensive natural gas. Any change in the legal environment that has the effect of blocking or delaying construction of new or expanded

${ }^{20}$ The economic forces that often yield a decision to flare natural gas are described in detail in Richard Pierce, State Regulation of Natural Gas in a Federally-Deregulated Market: The Tragedy of the Commons Revisited, 73 Cornell L. Rev. 15 (1987), cited in Northwest Central Pipeline Corp. v. State Corporation Commission of Kansas, 489 U.S. 493, 502 (1989). The circumstances that are leading to flaring today are described in Klass \& Meinhardt, supra, note 6, at 1009-1015. 
natural gas pipelines will impair efforts to mitigate climate change.

Respectfully submitted,

RICHARD J. PIERCE, JR.

Counsel of Record

GEORGe WASHINGTON UNIVERSITY

LAW SCHOOL

2000 H Street NW

Washington, DC 20052

(703) 304-1623

rpierce@law.gwu.edu

November 5, 2019 